\title{
Temporal and spatial variation in active layer depth in the McMurdo Sound Region, Antarctica
}

\author{
LEAH S. ADLAM ${ }^{\mathbf{1}}$, MEGAN R. BALKS ${ }^{\mathbf{1}}$, CATHY A. SEYBOLD ${ }^{\mathbf{2}}$ and DAVID I. CAMPBELL ${ }^{\mathbf{1}}$ \\ ${ }^{I}$ Department of Earth \& Ocean Sciences, University of Waikato, Private Bag 3105, Hamilton, New Zealand \\ ${ }^{2}$ United States Department of Agriculture, National Resource Conservation Service, 100 Centennial Mall North, Federal Building, \\ Rm 152, Lincoln, NE 68508-3866, USA \\ *m.balks@waikato.ac.nz
}

\begin{abstract}
A soil climate monitoring network, consisting of seven automated weather stations, was established between 1999 and 2003, ranging from Minna Bluff to Granite Harbour and from near sea level to about $1700 \mathrm{~m}$ on the edge of the polar plateau. Active layer depth was calculated for each site for eight successive summers from 1999/2000 to 2006/2007. The active layer depth varied from year to year and was deepest in the warm summer of 2001-02 at all recording sites. No trends of overall increase or decrease in active layer depth were evident across the up-to-eight years of data investigated. Average active layer depth decreased with increasing latitude from Granite Harbour $\left(77^{\circ} \mathrm{S}\right.$, active layer depth of $\left.>90 \mathrm{~cm}\right)$ to Minna Bluff $\left(78.5^{\circ} \mathrm{S}\right.$, active layer depth of $\left.22 \pm 0.4 \mathrm{~cm}\right)$, and decreased with increasing altitude from Marble Point (50 $\mathrm{m}$ altitude, active layer depth of $49 \pm 9 \mathrm{~cm}$ ) through to Mount Fleming $(1700 \mathrm{~m}$ altitude, active layer depth of $6 \pm 2 \mathrm{~cm}$ ). When all data from the sites were grouped together and used to predict active layer depth the mean summer air temperature, mean winter air temperature, total summer solar radiation and mean summer wind speed explained $73 \%$ of the variation $\left(\mathrm{R}^{2}=0.73\right)$.
\end{abstract}

Received 9 December 2008, accepted 8 June 2009

Key words: active layer prediction, altitudinal gradient, Cryosol, Gelisol, latitudinal gradient, permafrost, soil temperature

\section{Introduction}

Global temperatures are predicted by the International Panel for Climate Change (IPCC 2007, table SPM.1) to increase by $1.8-4.0^{\circ} \mathrm{C}$ by 2099 . The polar regions are expected to have a magnified response to the projected increase in global temperatures compared to more temperate regions (Kane et al. 1991). Increased air temperature will have an impact on the active layer and permafrost. The active layer is defined as the layer of ground subject to annual freezing and thawing cycles in areas underlain by permafrost (Linell \& Tedrow 1981, Guglielmin 2006), while permafrost is defined as the ground that remains continuously at or below $0^{\circ} \mathrm{C}$ for more than two years (Muller 1947, Linell \& Tedrow 1981).

The active layer has been predicted to be significantly impacted by the projected increase in air temperature over the next several decades (Kane et al. 1991) particularly in Alaska where the mean annual air temperature is about $0^{\circ} \mathrm{C}$. Kane et al. (1991) predicted that the active layer depth in Alaska will increase by $22 \mathrm{~cm}$ if mean annual air temperature warms by $2^{\circ} \mathrm{C}$ over the next 50 years, and an increase of $43 \mathrm{~cm}$ depth was predicted if air temperature was to warm by $4^{\circ} \mathrm{C}$ over a 50 year period.

The active layer depth in Antarctic soils provides a potential indicator of climate change (Guglielmin 2004) due to its sensitivity to changes in air temperature (Kane et al. 1991, Conovitz et al. 2006). Vegetation, which influences the relationship between active layer depth and surface climate parameters, is absent in the Ross Sea region of Antarctica (Guglielmin 2006).

The active layer depth in Antarctica has been shown to be spatially variable (Campbell et al. 1998, Bockheim \& Hall 2002, Bockheim et al. 2007, Ikard et al. 2009) and is also dependent on the climatic zone in which the site is located (Weyant 1966, Campbell \& Claridge 1987). For example, Coastal Zone sites may have active layer depths of about 50-60 cm (Campbell et al. 1998, Bockheim et al. 2007) whereas sites in the Inland Mountain subzone may have active layer depths on the order of about $5-10 \mathrm{~cm}$ (McKay et al. 1998, Bockheim et al. 2007).

With projected increases in global air temperature potentially impacting the active layer and permafrost, it is important to understand how the active layer varies interannually, what drives the interannual variation and the trends in active layer depth across latitude and altitude, before attempting to predict the impacts of climate change on active layer depth. Measurements of the active layer from a single season in the McMurdo Sound region of Antarctica have been conducted previously (e.g. Guglielmin et al. 2003, Conovitz et al. 2006) but there is a paucity of work concerning the interannual variation in active layer depth.

Seven automated weather stations have been established in the McMurdo Sound Region since 1999 and are located at Wright Valley at the base of Bull Pass (established 


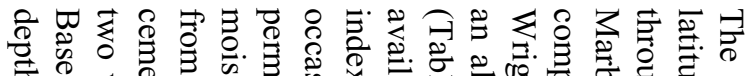

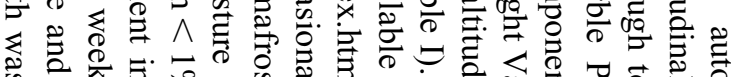
的导

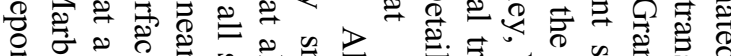

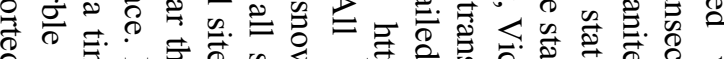

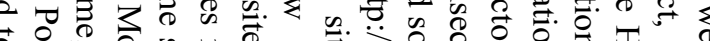

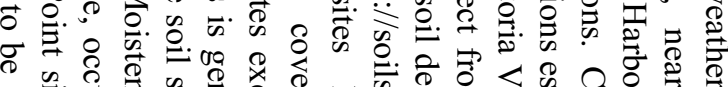

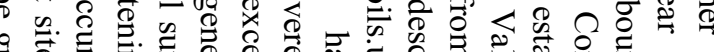

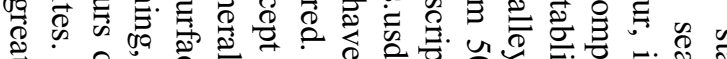

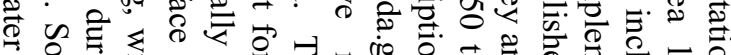

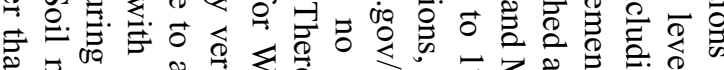

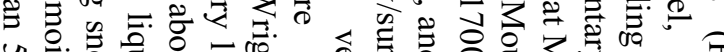

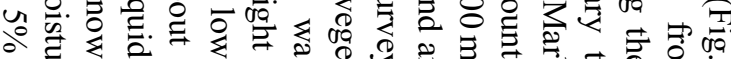
के है

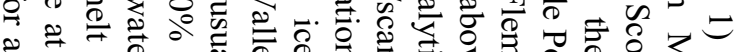

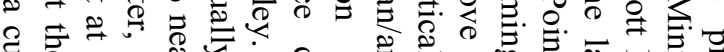

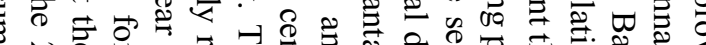

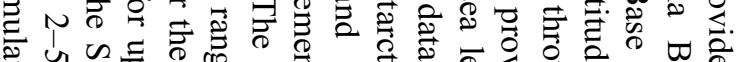

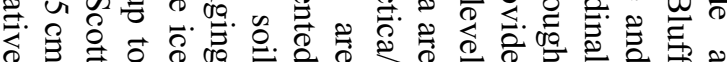
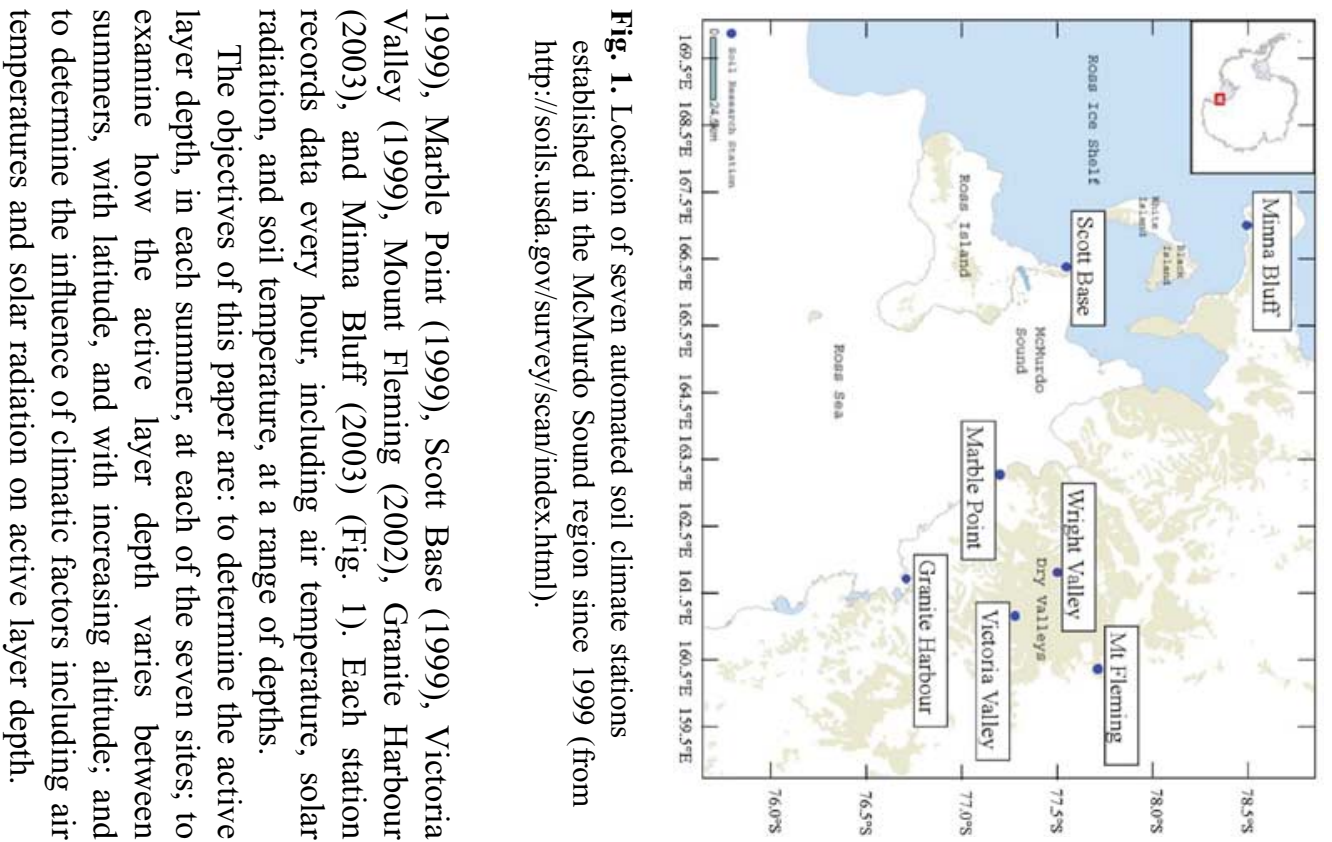

Table I. Site location and descriptions of automated weather stations established since 1999 in the McMurdo Sound region, Antarctica.

\begin{tabular}{|c|c|c|c|c|c|c|}
\hline $\begin{array}{l}\text { Site } \\
\text { (Length of record) }\end{array}$ & $\begin{array}{l}\text { GPS } \\
\text { location }\end{array}$ & $\begin{array}{l}\text { Site } \\
\text { location }\end{array}$ & $\begin{array}{l}\text { Elevation aspect, } \\
\text { and topography }\end{array}$ & $\begin{array}{l}\text { Mean annual air temp. } \\
\left({ }^{\circ} \mathrm{C}\right) \text { and soil classification }\end{array}$ & $\begin{array}{l}\text { Soil parent material } \\
\text { and texture }\end{array}$ & $\begin{array}{l}\text { General } \\
\text { comments }\end{array}$ \\
\hline $\begin{array}{l}\text { Minna Bluff } \\
(2004-2006)\end{array}$ & $\begin{array}{l}78^{\circ} 30^{\prime} 41.6^{\prime \prime S} \\
166^{\circ} 45^{\prime} 58^{\prime \prime} \mathrm{E}\end{array}$ & $\begin{array}{l}\text { N side of Minna } \\
\text { Bluff Peninsula, } 75 \mathrm{~km} \\
\mathrm{~S} \text { of Scott Base }\end{array}$ & $\begin{array}{l}37 \mathrm{~m} \text {, flat, strongly } \\
\text { developed low centred } \\
\text { polygons }\end{array}$ & -19 Typic Haploturbel & $\begin{array}{l}\text { Basalt dominated till, } \\
\text { gravelly sand over gravelly } \\
\text { clay loam }\end{array}$ & $\begin{array}{l}\text { High wind, some data } \\
\text { lost due to wind damage }\end{array}$ \\
\hline $\begin{array}{l}\text { Scott Base } \\
(1999-2007)\end{array}$ & $\begin{array}{l}77^{\circ} 50^{\prime} 53.6^{\prime \prime S} \\
166^{\circ} 45^{\prime} 44^{\prime \prime} \mathrm{E}\end{array}$ & $\begin{array}{l}\text { Hillside } 100 \mathrm{~m} \mathrm{~N} \\
\text { of Scott Base buildings }\end{array}$ & $\begin{array}{l}38 \mathrm{~m}, \mathrm{SSE} \text {, slope of } 6^{\circ} \text {, } \\
\text { weakly patterned ground }\end{array}$ & -19 Typic Haplorthel & $\begin{array}{l}\text { Scoria dominated till over } \\
\text { basalt bedrock, stony gravelly } \\
\text { sand }\end{array}$ & \\
\hline $\begin{array}{l}\text { Marble Point } \\
(1999-2007)\end{array}$ & $\begin{array}{l}77^{\circ} 25^{\prime} 10.6^{\prime \prime S} \\
163^{\circ} 40^{\prime} 55^{\prime \prime} \mathrm{E}\end{array}$ & $\begin{array}{l}400 \mathrm{~m} \text { E of the Wilson- } \\
\text { Piedmont Glacier }\end{array}$ & $\begin{array}{l}50 \mathrm{~m} \text {, flat, weakly } \\
\text { patterned ground }\end{array}$ & -18 Calcic Haplorthel & $\begin{array}{l}\text { Marble dominated till, } \\
\text { bouldery stony gravelley sand }\end{array}$ & \\
\hline $\begin{array}{l}\text { Granite Harbour } \\
(2004-2007)\end{array}$ & $\begin{array}{l}77^{\circ} 00^{\prime} 23.7^{\prime \prime S} \\
162^{\circ} 31^{\prime} 32.4^{\prime \prime} \mathrm{E}\end{array}$ & $\begin{array}{l}10 \mathrm{~m} \text { wide bouldery } \\
\text { bench between base of } \\
\text { cliff and sea ice edge }\end{array}$ & $\begin{array}{l}4 \mathrm{~m}, \mathrm{~N} \text {, gently sloping site } \\
\text { with high, steep slope } \\
\text { immediately to the south }\end{array}$ & -18 Typic Haplorthel & $\begin{array}{l}\text { Granitic colluvium over } \\
\text { possible beach sand, bouldery } \\
\text { gravelly coarse sand over fine sand }\end{array}$ & $\begin{array}{l}\text { "Night-time" shading } \\
\text { in summer }\end{array}$ \\
\hline $\begin{array}{l}\text { Wright Valley } \\
(1999-2007)\end{array}$ & $\begin{array}{l}77^{\circ} 31^{\prime} 06.1^{\prime \prime S} \\
161^{\circ} 51^{\prime} 57^{\prime \prime E}\end{array}$ & $\begin{array}{l}\text { On the floor of the } \\
\text { Wright Valley near the } \\
\text { base of Bull Pass }\end{array}$ & $\begin{array}{l}150 \mathrm{~m}, \mathrm{~S} \text {, gently sloping } \\
\text { colluvial fan from Bull Pass }\end{array}$ & -20 Salic Anhyorthel & $\begin{array}{l}\text { Granite dominated till and } \\
\text { colluvium, gravelly sand } \\
\text { over sandy loam }\end{array}$ & $\begin{array}{l}\text { No ice cement. } \\
\text { Snowfalls sublimate within } \\
\text { a few hours }\end{array}$ \\
\hline $\begin{array}{l}\text { Victoria Valley } \\
\text { (1999-2007) }\end{array}$ & $\begin{array}{l}77^{\circ} 19^{\prime} 51.3^{\prime \prime S} \\
161^{\circ} 36^{\prime} 02.2^{\prime \prime} \mathrm{E}\end{array}$ & $\begin{array}{l}\text { Valley floor } 30 \mathrm{~m} \\
\text { from Lake Victoria }\end{array}$ & $\begin{array}{l}410 \mathrm{~m} \text {, flat, strongly } \\
\text { developed low-centred } \\
\text { polygons }\end{array}$ & -20 Typic Haplorthel & $\begin{array}{l}\text { Granite dominated till, } \\
\text { gravelly sand over sand }\end{array}$ & \\
\hline $\begin{array}{l}\text { Mount Fleming } \\
\text { (2003-2007) }\end{array}$ & $\begin{array}{l}77^{\circ} 32^{\prime} 42.7^{\prime \prime S} \\
166^{\circ} 17^{\prime} 24.6^{\prime \prime} \mathrm{E}\end{array}$ & $\begin{array}{l}\text { Cirque on } \mathrm{N} \text { side of } \\
\text { Mount Fleming, near } \\
\text { edge of polar plateau }\end{array}$ & $\begin{array}{l}1700 \mathrm{~m} \text {, flat, strongly } \\
\text { developed high-centred } \\
\text { polygons }\end{array}$ & $-23^{*}$ Typic Haploturbel & $\begin{array}{l}\text { Dolerite dominated ablation } \\
\text { till, gravelly sand over } \\
\text { gravelly sandy loam. }\end{array}$ & $\begin{array}{l}\text { Constant strong cold } \\
\text { air drainage from } \\
\text { polar plateau }\end{array}$ \\
\hline
\end{tabular}

* Mean annual air temperature could only be calculated for Mount Fleming in 2007, as this was the only year in which a full dataset was available. 
average of 36 days per summer at Scott Base, 13 days per summer at Marble Point and one hour per summer at Wright Valley (Wall et al. 2004). Liquid moisture rarely occurs at Mount Fleming due to cold temperatures, Minna Bluff would probably have a similar moisture regime to Scott Base, and Victoria Valley is expected to be similar to Wright Valley. Granite Harbour has meltwater from an adjacent hillside flowing through the subsurface soil for much of the summer period.

Surface albedos are $10 \%$ at Scott Base, $25 \%$ at Marble Point, and $21 \%$ at Wright Valley (Balks et al. 2002). Given the similarity of geological materials, the albedo at Minna Bluff and Mount Fleming are expected to be similar to the albedo at Scott Base. Victoria Valley and Granite Harbour would be expected to have albedos similar to Wright Valley.

The apparent thermal diffusivities of soils at Scott base and in the McMurdo Dry Valleys were reported to be relatively low $\left(1.2 \times 10^{-7}-1.4 \times 10^{-7} \mathrm{~m}^{2} \mathrm{~s}^{-1}\right)$ and thermal conductivities were similar for all soils (about $0.2 \mathrm{Wm}^{-1} \mathrm{~K}^{-1}$ ) and relatively constant through the range of soil moisture content found in the field (Campbell et al. 1997). Ikard et al. (2009) reported similar mean bulk apparent thermal diffusivities $\left(2.9 \times 10^{-7}\right.$ $-116 \times 10^{-7} \mathrm{~m}^{2} \mathrm{~s}^{-1}$ ) in the Taylor Valley with the higher values in moist soils near lake margins.

\section{Instrumentation}

Soil pits were dug into the ice cement, where present, to depths of $120 \mathrm{~cm}$, or as deep as possible, to install the temperature probes. Care was taken to ensure the soil was returned as closely as possible to the original site condition.

Soil temperatures used to calculate active layer depth in this study were measured using two kinds of sensors. MRC (Measurement Research Corporation, Gig Harbor, WA) temperature probes were installed to $120 \mathrm{~cm}$ depth at Marble Point, Wright Valley and Victoria Valley, and to $115.6 \mathrm{~cm}$ depth at Scott Base. Each MRC probe measures temperatures at 11 depths over the $120 \mathrm{~cm}$ length of the probe. Temperature sensors (model 107; Campbell Scientific, Logan, UT) were used at Mount Fleming (to $75 \mathrm{~cm}$ depth) and Minna Bluff (to $84 \mathrm{~cm}$ depth up until the 2006 summer). A combination of MRC and 107 temperature probe measurements were used at Granite Harbour (to $90 \mathrm{~cm}$ depth) and at Minna Bluff (to $112 \mathrm{~cm}$ depth) after 2006. The location and depths of all temperature probes at each site are available at http://soils. usda.gov/survey/scan/antarctica/index.html.

Incoming solar radiation was measured $3 \mathrm{~m}$ above ground level using a pyranometer (LiCor model LI200X; Campbell Scientific, Logan, UT) at Wright Valley, Scott Base, Marble Point, Minna Bluff, Granite Harbour and Mount Fleming, and $2 \mathrm{~m}$ above ground level at Victoria Valley.

Air temperature was measured using an RM Young RTD temperature probe (model 43347; Campbell Scientific, Logan, UT) at Wright Valley (1.6 m above ground level).

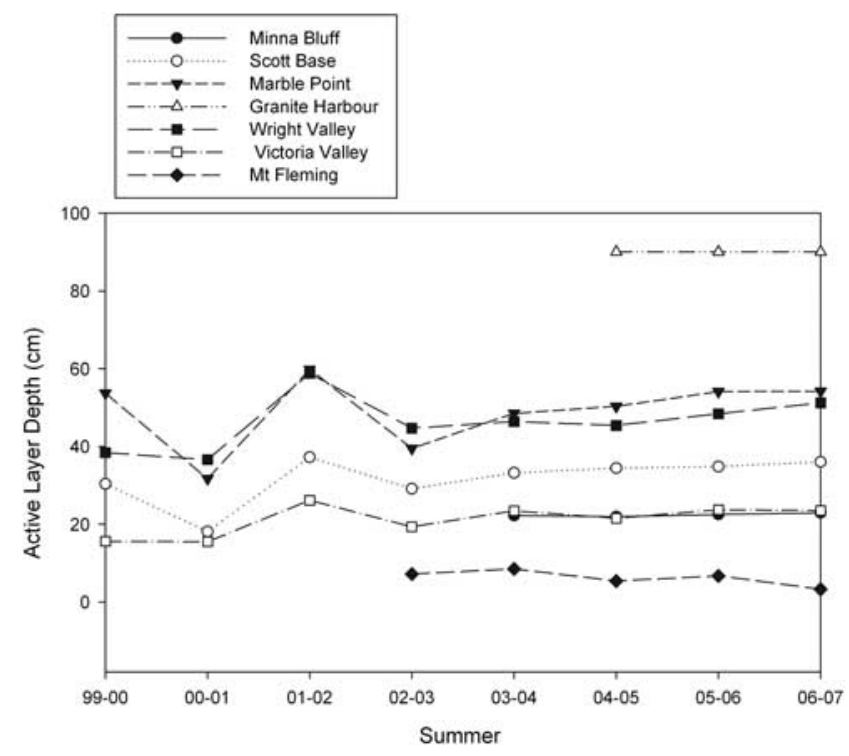

Fig. 2. Maximum summer active layer depths at seven sites in the McMurdo Sound region, from December 1999 to January 2007.

A Vaisala temperature and relative humidity probe was used at Scott Base (model HMP35C until January 2005, when it was replaced by HMP45C; Campbell Scientific, Logan, UT) (1.6 m), Victoria Valley (HMP45C) (2 m), and at Marble Point (HMP45C) $(1.6 \mathrm{~m})$. Air temperature at Minna Bluff was measured using a Vaisala temperature and relative humidity probe (HMP35C) until January 2006, after which a Campbell Scientific 107 probe in a solar radiation shield was installed $2 \mathrm{~m}$ above ground level. A Campbell Scientific 107 temperature probe in a solar radiation shield was used at Mount Fleming $(1.6 \mathrm{~m})$ and at Granite Harbour (2 m).

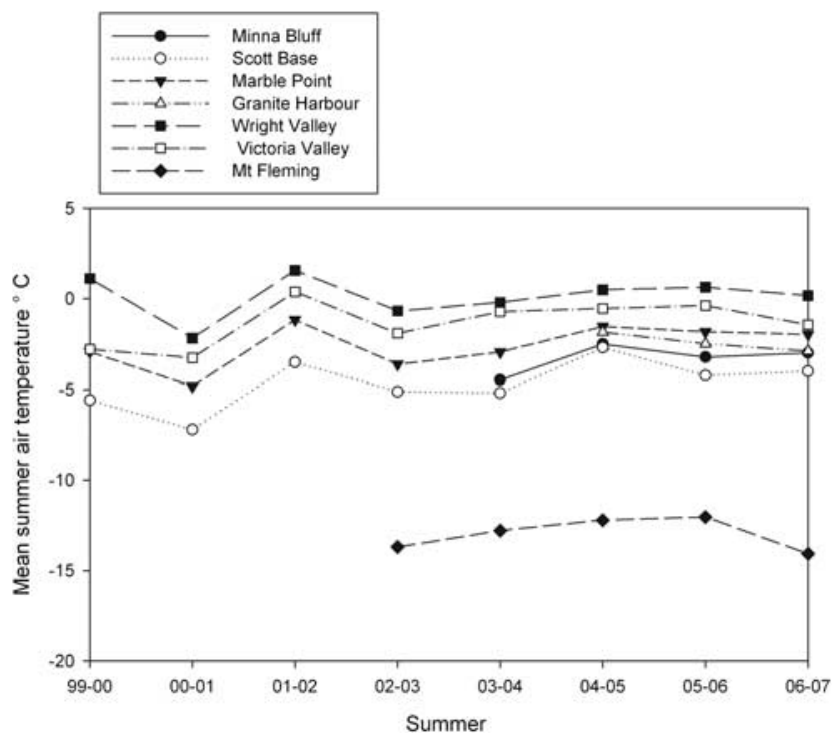

Fig. 3. Mean summer (December-January) air temperature $\left({ }^{\circ} \mathrm{C}\right)$ at all sites in McMurdo Sound region of Antarctica. 
Table II. Date (d/m/y) when the maximum active layer depth occurred in each summer at seven sites in the McMurdo Sound region. NE denotes that the site was not established in this summer. The date of maximum depth was determined when the soil temperature reached its maximum at the two depths either side of the $0^{\circ} \mathrm{C}$ isotherm.

\begin{tabular}{cccccccc}
\hline Summer & Minna Bluff & Scott Base & Marble Point & Granite Harbour* & Wright Valley & Victoria Valley & Mount Fleming \\
\hline $1999-00$ & $\mathrm{NE}$ & $13 / 01 / 00$ & $17 / 01 / 00$ & $\mathrm{NE}$ & $18 / 01 / 00$ & $17 / 01 / 00$ \\
$2000-01$ & $\mathrm{NE}$ & $19 / 01 / 01$ & $30 / 01 / 01$ & $\mathrm{NE}$ & $26 / 01 / 01$ & $24 / 01 / 01$ \\
$2001-02$ & $\mathrm{NE}$ & $16 / 01 / 02$ & $14 / 01 / 02$ & $\mathrm{NE}$ & $18 / 01 / 02$ & $08 / 01 / 02$ \\
$2002-03$ & $\mathrm{NE}$ & $13 / 01 / 03$ & $29 / 01 / 03$ & $\mathrm{NE}$ & $15 / 01 / 03$ & $05 / 01 / 03$ \\
$2003-04$ & $17 / 01 / 04$ & $12 / 01 / 04$ & $13 / 01 / 04$ & - & $10 / 01 / 04$ & $10 / 01 / 04$ \\
$2004-05$ & $23 / 01 / 05$ & $14 / 01 / 05$ & $22 / 01 / 05$ & $12 / 01 / 05$ & $20 / 01 / 05$ & $18 / 01 / 05$ \\
$2005-06$ & $09 / 01 / 06$ & $04 / 01 / 06$ & $18 / 01 / 06$ & $18 / 01 / 06$ & $18 / 01 / 06$ & $18 / 01 / 06$ \\
$2006-07$ & $13 / 01 / 07$ & $31 / 01 / 07$ & $30 / 01 / 07$ & $29 / 01 / 07$ & $14 / 01 / 07$ & $26 / 01 / 07$ & $31 / 01 / 03$ \\
\hline
\end{tabular}

*Date of occurrence at Granite Harbour was taken at the date of the maximum soil temperature at the deepest sensor $(90 \mathrm{~cm})$.

All sensors were connected to dataloggers (CR10X-2M; Campbell Scientific, Logan, UT). Atmospheric measurements were taken once every $10 \mathrm{sec}$ and soil measurements were taken once every $20 \mathrm{~min}$. All measurements were averaged every hour and the hourly average recorded. Data were manually downloaded each January.

\section{Active layer determination}

Active layer depth was determined by the intercept of the annual maximum soil temperature profile with the $0^{\circ} \mathrm{C}$ isotherm (Burn 1998, Guglielmin et al. 2003). This method is reliable because it is replicable and not influenced by subjective observers (Burn 1998) and data at our sites are continuously recorded all year. In this study, the austral summer is defined as the time from 1 December-31 January. For calculation of active layer depth at least 7 and up to 13 temperature-depth measurements were used at each site.

\section{Statistical analysis}

Correlation and regression analyses were undertaken using Minitab (Minitab Inc 2007) and Microsoft Excel (v. 2007).

\section{Results and discussion}

\section{Active layer depth}

The maximum active layer depth at the seven sites (Fig. 2) varied spatially and temporally (between summers). The active layer depths at sites in the coastal climatic zone (Scott Base (mean $32 \mathrm{~cm}$, SD 6), Marble Point (mean $49 \mathrm{~cm}$, SD 9), and Granite Harbour $(>90 \mathrm{~cm})$ ) were generally deeper than those further from the open sea (Minna Bluff (mean $22 \mathrm{~cm}$, SD 4), Wright Valley (mean $46 \mathrm{~cm}$, SD 7), Victoria Valley (mean $21 \mathrm{~cm}$, SD 4), and Mount Fleming (mean $6 \mathrm{~cm}$, SD 2)).

The between-summer variability in active layer depths (Fig. 2) showed a similar pattern to mean summer air temperature (Fig. 3). While there were between-summer differences there was no trend of increasing or decreasing active layer depth over the period investigated. Due to the limited length of the available record and the interannual variability in active layer depth it will be necessary to continue the monitoring for a much longer period to determine any long-term trends in active layer depth.

While Mount Fleming had the coldest summer temperatures and the shallowest active layer, the pattern was not consistent. Granite Harbour, with the deepest active layer, had mean summer air temperatures that were not significantly different from those at the other low altitude sites (Adlam 2009). While Wright Valley and Marble Point had similar active layer depths the mean summer air temperature was markedly warmer at Wright Valley.

Local micro-topography may influence active layer depth (Cannone et al. 2008). The greater active layer depth at Granite Harbour was probably the result of heat transfer from meltwater that was observed to percolate through the subsurface from the adjacent hillside. In the Taylor Valley deeper active layer depths have been shown to occur at moist sites, than in adjacent dry sites, as a result of increased thermal conductivity in moist soils (Ikard et al. 2009), and as a result of heat transfer via sub-surface water flow (Conovitz et al. 2006). The shallow active layer at Mount Fleming was within the range expected for sites in the Inland Mountain subzone (about 5-10 cm, McKay et al. 1998, Bockheim et al. 2007). The Mount Fleming site was near the edge of the polar plateau and subject to, near constant, strong winds derived from cold air drainage from the polar plateau. The Minna Bluff site, situated on the north side of the Minna Bluff Peninsula, was also a site subject to frequent severe winds. All other sites were on generally flat areas with minimal effects from meltwater runoff and had relatively "normal" Antarctic wind conditions.

The date of maximum soil temperatures used to calculate the active layer depth varied interannually (Table II). The time of maximum active layer depth ranged in occurrence from late December to late January.

Over half $(57 \%)$ of the recorded dates of maximum thaw were between 10 and 20 January with a further quarter (27\%) in late January (21-30). Early January (1-9) maximums were recorded twice at Victoria Valley and once each at Scott Base and Minna Bluff. At the relatively cold and windy 


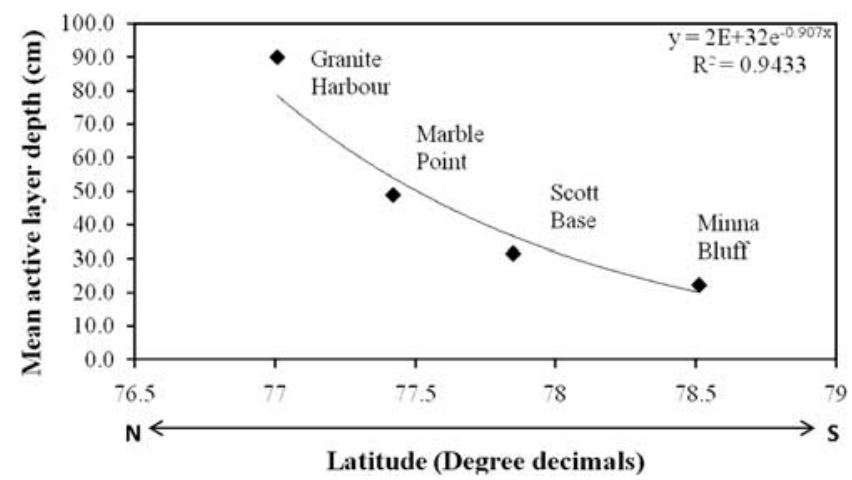

Fig. 4. Mean active layer depth $(\mathrm{cm})$ along a latitudinal transect from Minna Bluff $\left(78.5^{\circ} \mathrm{S}\right)$ through Scott Base $\left(77.8^{\circ} \mathrm{S}\right)$, Marble Point $\left(77.4^{\circ} \mathrm{S}\right)$ and Granite Harbour $\left(77.0^{\circ} \mathrm{S}\right)$ over the 1999-2007 period.

Mount Fleming site, maximum temperatures were recorded in December in three summers with the remaining two summers recording maximum temperatures in late January. In the cold summer of 2000-01 three of the four recording sites had maximum temperatures in late January, probably due to the extended period of cool, cloudy, weather experienced across the region in the first half of January 2001. There were no obvious trends between date of maximum thaw and specific site factors, such as albedo or microtopography, given that all sites varied from summer to summer. The factor most likely to be affecting the timing of maximum thaw is the summer weather pattern. A two or three week pattern of warm sunny, or cool cloudy, weather in early January could have a strong influence.

\section{Change in active layer depth with latitude and altitude}

As would be widely expected the active layer depth showed clear latitudinal (Fig. 4) and altitudinal (Fig. 5) gradients. The latitudinal gradient in Fig. 4 may be somewhat exaggerated due to the local topographic effects at Granite Harbour, discussed previously.

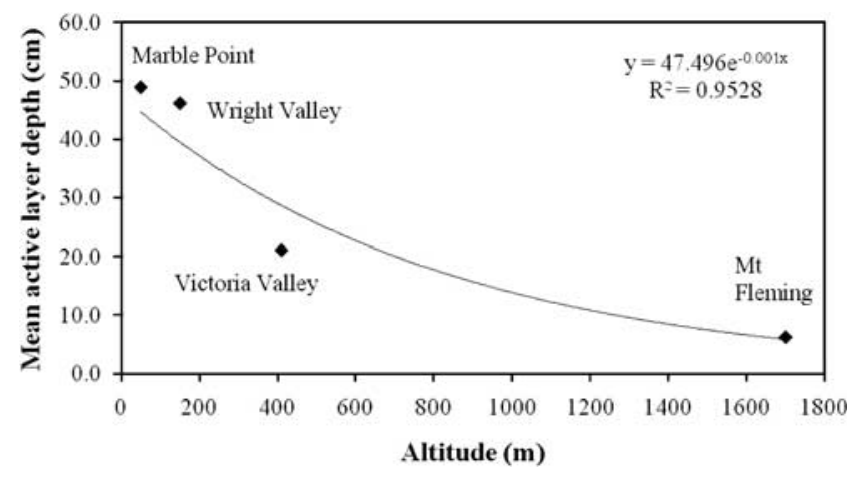

Fig. 5. Mean active layer depth $(\mathrm{cm})$ along an altitudinal gradient from Marble Point through to Wright Valley, Victoria Valley and Mount Fleming.

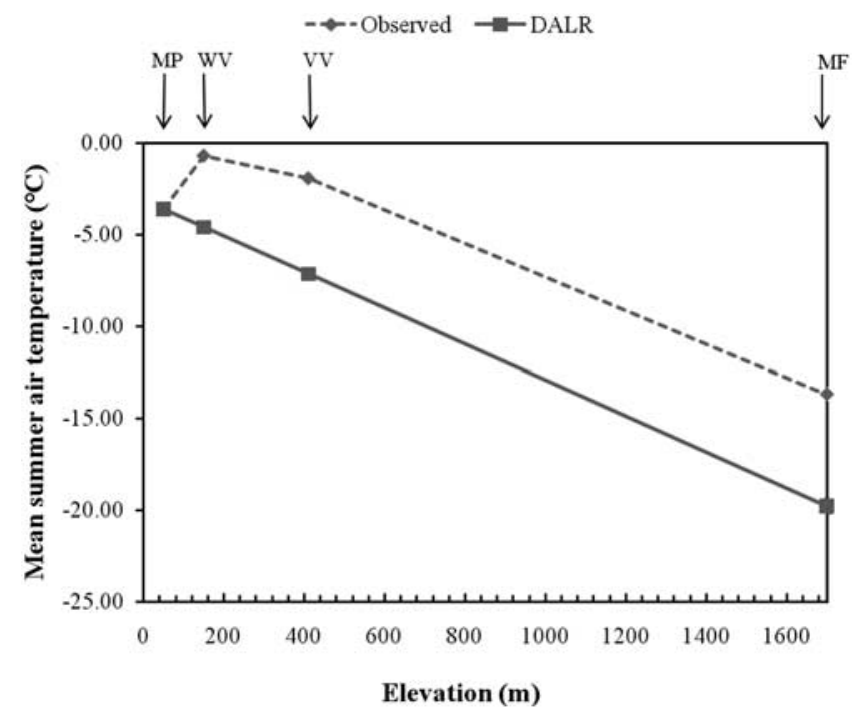

Fig. 6. Elevation vs observed and predicted 2002-03 summer air temperatures. Predictions are based on a dry adiabatic lapse rate (DALR) of $0.98^{\circ} \mathrm{C}$ decrease per $100 \mathrm{~m}$ increase in elevation, and are calculated relative to Marble Point. $\mathrm{MP}=$ Marble Point, $\mathrm{WV}=$ Wright Valley, $\mathrm{VV}=$ Victoria Valley and $\mathrm{MF}=$ Mount Fleming.

Hatherton (1990) suggested that the maximum dry adiabatic lapse rate could be used to estimate temperature differences based on elevation differences in Antarctica, which in turn explains the decrease in active layer depth with increasing elevation (Campbell \& Claridge 2006). Between the Wright Valley and Mount Fleming, the observed temperature increase had the same slope as that predicted by the dry adiabatic lapse rate (Fig. 6), with the decrease in air temperature conforming to that predicted due to the adiabatic lapse rate. However, the dry adiabatic lapse rate did not predict the temperature difference between Marble Point and the higher altitude, Wright Valley. The Marble Point site is within the Coastal Mountain climate zone of Campbell \& Claridge (1987), while the other sites are within the Inland Mountain zone. It is clear that the differences in active layer depth between the climate zones, as illustrated by the difference between Marble Point and Wright Valley, are not attributable to altitude alone.

\section{The 2001-02 warm summer}

The active layer depths at all operational sites (Scott Base, Marble Point, Wright Valley and Victoria Valley) were deepest in the summer of 2001-02 which was one of the warmest summers on record in the McMurdo Dry Valleys (Foreman et al. 2004, Barrett et al. 2008) and also in the western Antarctic Peninsula and the Bellingshausen Sea (Massom et al. 2006). The warm temperatures experienced in the 2001-02 summer in the Antarctic Peninsula were 
caused by the presence of a "blocking high" (Turner et al. 2002, Massom et al. 2006), that persisted from midSeptember to February, and was linked, by the British Antarctic Survey, to the positive phase of the Southern Annular Mode (Massom et al. 2006). Turner et al. (2002) noted that there was an anomalously low mean sea level pressure situation over the same period (2001-02) in the Ross Ice Shelf region, which may have been a contributing factor to the warmer surface air temperatures and thus deeper active layer depths recorded.

\section{Relationship between active layer depth and climatic variables}

Mean summer air temperature and mean summer windspeed

Summer air temperature (December-January) has been documented to have a strong influence on the depth of the active layer (Zhang et al. 1997, Conovitz et al. 2006, Bockheim et al. 2007). Guglielmin (2004) noted the strong relationship between ground surface and air temperature $\left(\mathrm{R}^{2}>0.9\right)$ in the Ross Sea Region. Conovitz et al. (2006) found that the active layer depth in the McMurdo Dry Valleys could respond to changes in air temperature within a time period as short as 24 hours.

Active layer depth correlated positively with mean summer air temperature (1 December-31 January) at Scott Base $(\mathrm{R}=0.87)$, Marble Point $(\mathrm{R}=0.91)$, Wright Valley $(\mathrm{R}=0.92)$ and Victoria Valley $(\mathrm{R}=0.94)$. However, Mount Fleming $(\mathrm{R}=0.24)$ and Minna Bluff $(\mathrm{R}<0.1)$ showed no relationship between mean summer air temperature and active layer depth. Both Minna Bluff and Mount Fleming are subject to strong winds (with annual average wind speed of $8.8 \mathrm{~m} \mathrm{~s}^{-1}$ at Minna Bluff and $10.1 \mathrm{~m} \mathrm{~s}^{-1}$ at Mount Fleming) and had shorter temperature records available.

Mean summer wind speed gave a positive correlation with active layer depth between summers at Minna Bluff $(\mathrm{R}=0.93)$, Wright Valley $(\mathrm{R}=0.76)$, Victoria Valley $(\mathrm{R}=0.65)$ and Mount Fleming $(\mathrm{R}=0.56)$. However there was no relationship between mean summer wind speed and active layer depth at Marble Point $(\mathrm{R}=-0.2)$ or Scott Base $(\mathrm{R}=0.2)$. Granite Harbour was not included as all values for active layer depth were greater than $90 \mathrm{~cm}$ and no correlation coefficient was able to be calculated.

Mean winter air temperature

Within each site over time, the correlation between active layer depth and mean winter air temperature (1 June-31 August in the previous winter) for each site was poor ( $R$ values of -0.40 to 0.18 ) except Minna Bluff $(R=0.78)$. The poor relationship between mean winter air temperature and active layer depth suggested that the between summer variability in active layer depth at each individual site, except Minna Bluff, responded more to the summer air temperature than to the winter air temperature.
Solar radiation

The correlation between active layer depth and total summer solar radiation (1 December-31 January) at each site was poor ( $\mathrm{R}$ values of -0.5 to +0.2 ). The absorption or loss of solar radiation at the soil surface, and thus the amount of heating for the soil profile is expected to be influenced by the surface albedo (Balks et al. 1995, Campbell et al. 1997, 1998). However, the lower albedo sites (Scott Base, Minna Bluff, and Mount Fleming) did not have any improved relationship between solar radiation and active layer depth. Conovitz et al. (2006) also reported no statistically significant relationship between active layer depth and total incoming solar radiation.

\section{Prediction of active layer depth}

Zhang et al. (1997) showed that there can be no single variable that explains the spatial differences in parameters such as the active layer depth. For example, the mean summer air temperature is not an independent variable as it is affected by other factors such as solar radiation and wind speed. Therefore, a single factor regression of active layer depth and any climatic variable, such as mean summer air temperature, is not likely to fully explain the interannual variation in active layer depth. A step-wise multiple regression analysis with all sites (except Mount Fleming and Granite Harbour, due to missing data) pooled together gave the equation:

$$
\begin{aligned}
\mathrm{ALD}= & 222+5.69(\mathrm{MSAT})+3.63(\mathrm{MWAT})-10.6(\mathrm{TSSR}) \\
& -2.84(\mathrm{MSWS})
\end{aligned}
$$

Where $\mathrm{ALD}=$ active layer depth, MSAT = mean summer (December-January) air temperature, MWAT $=$ mean winter (June-August) air temperature, TSSR $=$ total summer solar radiation and MSWS = mean summer wind speed.

Mean summer air temperature, mean winter air temperature, total summer solar radiation and mean summer wind speed together explained $73 \%$ of the variation in the active layer depth across all the sites together. The regression had a residual standard deviation of 7.32, and was based on 34 observations across six sites. All four predictors made a significant contribution to the prediction of the active layer depth $(P<0.02)$. Mean summer air temperature alone explained $15 \%$ of the variation in active layer depth. When mean winter air temperature was added as a predictor variable (with mean summer air temperature), 65\% of variation in active layer depth could be explained. The $\mathrm{R}^{2}$ was further improved to 0.68 by including total summer solar radiation as a predictor variable. Adding the fourth predictor variable, mean summer wind speed improved the $\mathrm{R}^{2}$ to 0.73 . The regression equation may potentially be used as a predictor for active layer depth at sites in the McMurdo Sound region. 


\section{Limitations of the study}

The data available form a considerable, and increasingly valuable, database with good supporting soil and site description metadata. However, the interpretation of the data to determine longer-term trends is limited by the relatively short record thus far (eight years at four sites, four years at two sites and three years at one site). The data has further limitations due to incomplete records because of equipment malfunction, particularly in the winter months, with only one full year of data available for Mount Fleming. Also interpretation of the data has to be approached with caution due to some site-specific conditions, such as the occurrence of meltwater flow at Granite Harbour. However, these data do represent one of the most comprehensive soil climate datasets available in the Antarctic, extending through the active layer and into the top part of the permafrost.

\section{Conclusions}

The maximum active layer depth was calculated for eight consecutive summers (starting 1999/2000 and ending 2006/07) at seven sites located in the McMurdo Sound region. There was marked interannual variability in both the timing and depth of maximum thaw which was strongly influenced by between-summer variability in mean summer air temperatures. As expected, active layer depth showed clear latitudinal and altitudinal gradients. The local topography had a notable effect at Granite Harbour, where meltwater probably transferred heat to the subsurface and accelerated the thawing process.

Within each site, except for Minna Bluff and Mount Fleming, the active layer increased with increasing mean summer air temperature $(\mathrm{R}>0.87)$. At individual sites the between-summer differences in active layer depth did not correlate with mean winter air temperature except at Minna Bluff, nor did active layer depth correlate with total summer incoming solar radiation. Minna Bluff, while not strongly influenced by mean summer air temperature did exhibit an increase in active layer depth with both mean summer wind speed $(\mathrm{R}=0.9)$ and mean winter temperature $(\mathrm{R}=0.78)$.

When all sites (except Mount Fleming and Granite Harbour) were included together in multiple regression analysis, active layer depth was significantly influenced by mean summer air temperature, mean winter air temperature, total summer solar radiation and mean summer wind speed. When combined, the four predictors accounted for $73 \%$ of the variation in the active layer depth, providing a potential mechanism for prediction of active layer depth at other sites in the Ross Sea Region.

\section{Acknowledgements}

This research was partially funded by The New Zealand Foundation for Research Science and Technology, (FRST grant $\mathrm{CO} 9 \times 0307)$ and logistic support was provided by Antarctica New Zealand. Thanks to John Kimble, Ron Paetzold, Don Huffman, Iain Campbell, Jackie Aislabie and Deb Harms who have all assisted with initial climate station establishment and maintenance. Thanks also to Professor Ray Littler of the Statistics Department (University of Waikato) for assistance with statistical advice and analysis. Funding assistance for Leah Adlam from Education New Zealand facilitated collaboration on this paper between the University of Waikato and the USDA-NRCS in Lincoln, Nebraska. Thanks to the referees for helpful comments that led to improvements in the final paper.

\section{References}

AdLAm, L.S. 2009. Soil climate and permafrost monitoring in the McMurdo Sound region, Antarctica. MSc thesis, University of Waikato, 273 pp. [Unpublished.]

Balks, M.R., Campbell, D.I., Campbell, I.B. \& Claridge, G.G.C. 1995. Interim results of 1993-94 soil climate, active layer and permafrost investigations at Scott Base, Vanda and Beacon heights, Antarctica. University of Waikato, Antarctic Research Unit Special Report, No. 1, 64 pp.

Balks, M.R., Paetzold, R.F., Kimble, J.M., Aislabie, J. \& Campbell, I.B. 2002. Effects of hydrocarbon spills on the temperature and moisture regimes of Cryosols in the Ross Sea region. Antarctic Science, 14, 319-326.

Barrett, J.E., Virginia, R.A., Wall, D.H., Doran, P.T., Fountain, A.G., Welch, K.A. \& Lyons, W.B. 2008. Persistent effects of a discrete warming event on a polar desert ecosystem. Global Change Biology, 14, 2249-2261

Bockheim, J.G. \& Hall, K.J. 2002. Permafrost, active-layer dynamics and periglacial environments of continental Antarctica. South African Journal of Science, 98, 82-90.

Bockheim, J.G., Campbell, I.B. \& McLeod, M. 2007. Permafrost distribution and active-layer depths in the McMurdo Dry Valleys, Antarctica. Permafrost and Periglacial Processes, 18, 217-227.

Burn, C.R. 1998. The active layer: two contrasting definitions. Permafrost and Periglacial Processes, 9, 411-416.

Campbell, I.B. \& Claridge, G.G.C. 1987. Antarctica: soils, weathering processes and environment. New York: Elsevier Science Publishers, 368 pp.

Campbell, I.B. \& Claridge, G.G.C. 2006. Permafrost properties, patterns and processes in the TransAntarctic Mountains Region. Permafrost and Periglacial Processes, 17, 215-232.

Campbell, D.I., MacCulloch, R.J.L. \& Campbell, I.B. 1997. Thermal regimes of some soils in the McMurdo Sound region, Antarctica. In Lyons, W.B., Howard-Williams, C. \& Hawes, I., eds. Ecosystem processes in Antarctic ice-free landscapes. Rotterdam: A.A. Balkema, 45-55.

Campbell, I.B., Claridge, G.G.C., Campbell, D.I. \& Balks, M.R. 1998. Soil temperature and moisture properties of Cryosols of the Antarctic Cold Desert. Eurasian Soil Science, 31, 542-546.

Cannone, N., Wagner, D., Hubberten, H.W. \& Guglielmin, M. 2008. Biotic and abiotic factors influencing soil properties across a latitudinal gradient in Victoria Land, Antarctica. Geoderma, 144, 50-65.

Conovitz, P.A., MacDonald, L.H. \& McKnight, D.M. 2006. Spatial and temporal active layer dynamics along three glacial meltwater streams in the McMurdo Dry Valleys, Antarctica. Arctic, Antarctic and Alpine Research, 38, 42-53.

Foreman, C.M., Wolf, C.F. \& Priscu, J.C. 2004. Impact of episodic warming events on the physical, chemical and biological relationships of lakes in the McMurdo Dry Valleys, Antarctica. Aquatic Geochemistry, 10, 239-268. 
Guglielmin, M. 2004. Observations on permafrost ground thermal regimes from Antarctica and the Italian Alps, and their relevance to global climate change. Global and Planetary Change, 40, 159-167.

GuglieLmin, M. 2006. Ground surface temperature (GST), active layer and permafrost monitoring in continental Antarctica. Permafrost and Periglacial Processes, 17, 133-143.

Guglielmin, M., Balks, M.R. \& Paetzold, R. 2003. Towards and Antarctic active layer and permafrost monitoring network. In Proceedings of the Eighth International Conference on Permafrost, 21-25 July 2003, Zurich, Switzerland. Zurich: Balkema, 337-341.

Hatherton, T. 1990. Antarctica: the Ross Sea region. Wellington, New Zealand: DSIR Publishing, 287 pp.

Ikard, S.J., Goosef, M.N., Barrett, J.E. \& Takacs-Vesbach, C. 2009. Thermal characterisation of active layer across a soil moisture gradient in the McMurdo Dry Valleys, Antarctica. Permafrost and Periglacial Processes, 20, 27-39.

International Panel on Climate Change. 2007. Climate change 2007: synthesis report. http://www.ipcc.ch/pdf/assessment-report/ar4/syr/ar4_ syr_spm.pdf

Kane, D.L., Hinzman, L.D. \& Zarling, J.P. 1991. Thermal response of the active layer to climatic warming in a permafrost environment. Cold Regions Science and Technology, 19, 111-122.

Linell, K.A. \& Tedrow, J.C.F. 1981. Soil and permafrost surveys in the Arctic. Oxford: Oxford University Press, 279 pp.
Massom, R.A., Stammerjohn, S.E., Smith, R.C., Pook, M.J., Iannuzzi, R.A., Adams, N., Martinson, D.G., Vernet, M., Fraser, W.R., Quetin, L.B., Ross, R.M., Massom, Y. \& Krouse, H.R. 2006. Extreme anomalous atmospheric circulation in the West Antarctic Peninsula region in austral spring and summer 2001/02, and its profound impact on sea ice and biota. Journal of Climate, 19, 3544-3571.

McKay, C.P., Mellon, M.T. \& Friedmann, E.I. 1998. Soil temperatures and stability of ice-cemented ground in the McMurdo Dry Valleys, Antarctica. Antarctic Science, 10, 31-38.

MulLeR, S.W. 1947. Permafrost or permanently frozen ground and related engineering problems. Ann Arbor, MI: J.W. Edwards, 231 pp.

Turner, J., Harangozo, S.A., Marshall, G.J., King, J.C. \& Colwell, S.R. 2002. Anomalous atmospheric circulation over the Weddell Sea, Antarctic during the austral summer of 2001/02 resulting in extreme sea ice conditions. Geophysical Research Letters, 29, 10.1029/2002GL015565.

Wall, A.M., Balks, M.R., Campbell, D.I. \& Paetzold, R.F. 2004. Soil moisture measurement in the Ross Sea region of Antarctica using Hydra soil moisture probes. In SingH, B., ed. Supersoil 2004: Proceedings of the Third Australian New Zealand Soils Conference, December 2004, University of Sydney, Australia. Sydney: Australian Society of Soil Science, 9 pp.

Weyant, W.S. 1966. The Antarctic climate. Antarctic Research Series, 8 , $47-60$.

Zhang, T., Osterkamp, T.E. \& Stamnes, K. 1997. Effects of climate on the active layer and permafrost on the North Slope of Alaska, USA. Permafrost and Periglacial Processes, 8, 45-67. 